\title{
Studies pertaining to coagulant and proteolytic activities of plant proteases from Cynara cardunculus
}

\author{
Sofia V. Silva, F. Xavier Malcata * \\ Escola Superior de Biotecnologia, Universidade Catolica Portuguesa, Rua Dr. António Bernardino de Almeida, P-4200-072 Porto, Portugal
}

Keywords: Enzymes; Cheesemaking; Kinetics

\begin{abstract}
Studies encompassing variation of milk clotting time with the concentration of proteases extracted from Cynara cardunculus were performed; milk clotting time dependence is not linear, and a model was postulated that fits well the experimental data obtained, and hence may be useful in predicting changes during the cheesemaking process. Parallel studies were also conducted pertaining to proteolysis of a mixture of ovine and caprine caseins, in attempts to investigate the stability of the aforementioned coagulating enzymes in crude or in pure form, with or without previous incubation for a certain time under typical ripening conditions. The enzymes exhibited an increase in activity whenever previous incubation had taken place. Moreover, the extent of enzyme-mediated proteolysis was always higher on caprine than on ovine milk caseins.
\end{abstract}

\section{Introduction}

Rennet substitutes of plant origin have been increasingly used to manufacture cheese, especially at the artisanal level. Application of plant coagulants allows target cheese production, and hence contributes to improve the nutritional input of those populations on whom restrictions are imposed by use of animal rennets (Gupta \& Eskin, 1977). Several plant preparations have been shown (Aworth \& Muller, 1987; Domingos et al., 1997; Gupta et al., 1977; Edwards \& Kosikowski, 1983; Padmanabhan, Chitre, \& Shastri, 1993; Pozsar-Hajnal, Vamos-Vigyazo, Nonn-Sas, \& Hegedues-Voelgyesi, 1969; Singh, Chander, Bhalerao, \& Dastur, 1973; Tamer, 1993) to clot milk; however, the majority proved unsuitable for cheese production owing to their excessively proteolytic character - which lowers cheese yield and produces bitter flavours in the final cheese. Moreover, their toxin content constrains their use as food. Among those that have been reported to produce sat-

\footnotetext{
${ }^{*}$ Corresponding author. Tel.: +351-2255-80004; fax: +351-225090351.

E-mail address: xmalcata@esb.ucp.pt (F.X. Malcata).
}

isfactory final products, the proteases present in the flowers of Cynara cardunculus deserve special mention; aqueous extracts thereof have been used for centuries in the Iberian Peninsula for the manufacture, at the farm level, of ovine and/or caprine milk cheeses (Pires et al., 1994; Trujillo, Carretero, \& Guamis, 1994; Vieira de Sá $\&$ Barbosa, 1972). The clotting activity of such extracts is accounted for by two aspartic proteases, cardosins A and $\mathrm{B}$, which have been shown to act on $\kappa$-casein in a way similar to that of chymosin (Macedo, Faro, \& Pires, 1993), but which can also hydrolyse caseins other than к-casein (Silva \& Malcata, 1998; Silva \& Malcata, 1999).

Cheese production starts with milk coagulation, which involves the enzyme-mediated cleavage of $\kappa$-casein at the peptide bond Phe105-Met106; this chemical step renders the casein micelles unstable, and thus eventually causes cooperative aggregation to yield a clot - which is then ripened and gives rise to the final cheese. A few kinetic models were proposed (Hyslop, Richardson, \& Ryans, 1979; Kopelman \& Cogan, 1976; van Hooydonk \& Walstra, 1987) for milk coagulation by rennet, but information is still scarce concerning the kinetics of milk coagulation by enzymes of plant origin; as of today, there is indeed no model whatsoever, 
proposed and tested for milk coagulation by cardosins $\mathrm{A}$ and $\mathrm{B}$, either in a mixture or isolated. Such modelling would help, not only in attempts to illuminate the contribution of each cardosin to the general milk-clotting activity of that plant coagulant, but also for optimising clotting process so as to mechanistically predict its evolution as a function of a number of processing parameters.

Milk clotting enzymes affect final cheese quality via their hydrolytic action on $\alpha_{s^{-}}, \beta-$ and $\kappa$-caseins, even though only a residual amount of enzyme is retained in the curd after syneresis. Manufacturing and ripening conditions influence the protein degradation pattern of cheese insofar as they constrain the activity/stability of enzymes in terms of prevailing environmental conditions (e.g. $\mathrm{pH}, a_{\mathrm{w}}$ and temperature).

The major aim of this work was to generate experimental data on milk coagulation by cardosins A and B, and to examine the fit of existing mathematical models to these data - so as to ascertain whether milk clotting time by cardosins might be predictable. The integrity (in terms of kinetic stability) of these plant enzymes was also a secondary aim. A comparison was made with a mixture of both enzymes, in attempts to reveal interactions and to better understand what happens when such a coagulant is used in traditional cheesemaking.

\section{Materials and methods}

\section{Enzyme source}

Cardosins were extracted from the dried flowers of $C$. cardunculus, and purified by gel filtration followed by ion-exchange chromatography, according to the method described by Silva, Allmere, Malcata, and Andrén (2003). The lyophilized enzymes were reconstituted in citrate buffer ( $\mathrm{pH}$ 6.2) just prior to use, or alternatively reconstituted in $10 \mathrm{mM}$ citrate buffer $(\mathrm{pH} 5.0)$ containing $20 \mathrm{~g} / 1$ of $\mathrm{NaCl}$, at $10{ }^{\circ} \mathrm{C}$ for $20 \mathrm{~h}$, so as to mimic actual cheese ripening conditions.

\section{Protein conten tdetermination}

The protein concentration of each enzyme solution was determined by the phenol reagent method for biological fluids, using the micro protein determination method (Sigma, St. Louis MO, USA).

\section{Coagulating activity determination}

Milk clotting activity was determined following the procedure described by IDF (1992). Low-heat skim milk powder (NILAC ${ }^{\mathrm{TM}}$ ) (NIZO, Ede, The Netherlands) was reconstituted in $10 \mathrm{mM}$ aqueous $\mathrm{CaCl}_{2}(\mathrm{pH}$ 6.5) to a final concentration of $0.12 \mathrm{~kg} / \mathrm{l}$. Enzyme extracts were added at a rate of $0.1 \mathrm{ml}$ per $\mathrm{ml}$ of milk. The coagulation point was determined by manual rotating of the test tube periodically, at short time intervals, and checking for visible clot formation. One rennet unit (R.U.) was defined as the amount of protein that coagulates $10 \mathrm{ml}$ of reconstituted low-heat skim milk powder at $30^{\circ} \mathrm{C}$ in $100 \mathrm{~s}$ (Berridge, 1945). Standard solutions of each enzyme were prepared by diluting the enzymes in ultrapure water.

\section{Proteolytic activity determination}

Ovine (or caprine) casein (SIGMA), at the $1 \%(\mathrm{w} / \mathrm{v})$ level, was subjected to hydrolysis at $30{ }^{\circ} \mathrm{C}$ in $10 \mathrm{mM}$ citrate buffer ( $\mathrm{pH}$ 6.2). Sodium azide was added at $0.03 \%(\mathrm{w} / \mathrm{v})$ to prevent microbial growth. The hydrolysis was initiated by addition of $120 \mu 1$ of each enzyme solution (cardosin A, cardosin B, or a mixture of both enzymes) to $3 \mathrm{ml}$ of substrate solution. At selected times (5 min, 1, 3, 6 and $10 \mathrm{~h}$ ), aliquots were duly taken, and the reaction was quenched by heating at $100{ }^{\circ} \mathrm{C}$ for 5 min. The proteolytic activity was quantified by evaluating the peptides soluble in aqueous $5 \%(\mathrm{w} / \mathrm{v})$ trichloroacetic acid (TCA); aliquots of each sample were treated with $5 \%(\mathrm{w} / \mathrm{v})$ TCA at a volumetric ratio of $1: 2$; the mixture was allowed to settle for $10 \mathrm{~min}$, and then centrifuged at $12,000 \mathrm{~g}$ for $10 \mathrm{~min}$. The absorbance of the supernatant was measured at $280 \mathrm{~nm}$.

\section{Mathematical and statistical analyses}

\section{Coagulating activity}

The experimental data pertaining to variation of clotting time with enzyme concentration were examined by non-linear regression analysis, using the Statistica software (v. 5.1, Statsoft, Tulsa OK, USA), based on the model proposed by Payens, Wiersma, and Brinkhuis (1977).

$t E_{0}^{\gamma}=C$,

where $t$ denotes clotting time and $E_{0}$ total enzyme concentration, and where $\gamma$ and $C$ are adjustable parameters.

Diagnostics of residuals of the data fitted to by the aforementioned model (not shown) were performed, in order to check the validity of the statistical analyses; since no biased trends were detected, no data transformation was required, nor was transformation of the functional form of the model warranted, so Eq. (1) was assumed to be appropriate for fitting.

\section{Proteolytic activity}

Assuming that each substrate protein molecule (denoted as A) is hydrolysed into two peptide molecules (denoted as B), then the mass balance prevailing during hydrolysis and based on said stoichiometry is: 
$2\left(C_{\mathrm{A} 0}-C_{\mathrm{A}}\right)=C_{\mathrm{B}}$,

where $C_{x}$ is the concentration of entity $x$, and subscript 0 denotes initial conditions; for simplicity, the initial concentration of product B was taken as nil.

The simplest mechanistic equation for this event can thus be written as

$\mathrm{A} \rightarrow 2 \mathrm{~B}$,

which, assuming it represents an elementary chemical step, leads to

$r_{\mathrm{A}}=-k C_{\mathrm{A}}$,

where $r_{x}$ is the rate of production of entity $x$, and $k$ denotes a first-order kinetic constant. Integration of Eq. (4) in a batch system, the mass balance of which is characterized by

$\frac{\mathrm{d} C_{\mathrm{A}}}{\mathrm{d} t}=-r_{\mathrm{A}}$,

leads to

$C_{\mathrm{A}}=C_{\mathrm{A} 0} \mathrm{e}^{-k t}$,

where $t$ is the hydrolysis time.

Recall that the proteolytic activity is measured via quantification of the peptides soluble in $5 \%(\mathrm{w} / \mathrm{v}) \mathrm{TCA}$, which is based on a correlation with absorbance that is the sum of the absorbances (Abs) given by the intact caseins and the peptides formed so far, i.e.

$\operatorname{Abs}(t)=\left(\varepsilon_{\mathrm{A}} L C_{\mathrm{A}}\right)+\left(\varepsilon_{\mathrm{B}} L C_{\mathrm{B}}\right)$

where $\varepsilon_{\mathrm{A}}$ and $\varepsilon_{\mathrm{B}}$ denote the molar absorption coefficients for the substrate and the product, respectively, and $L$ denotes the absorption path length. Substituting Eqs. (2) and (5) in Eq. (7), followed by rearrangement, one obtains

$\operatorname{Abs}(t)=2 L \varepsilon_{\mathrm{B}} C_{\mathrm{A} 0}+L C_{\mathrm{A} 0}\left(\varepsilon_{\mathrm{A}}-2 \varepsilon_{\mathrm{B}}\right) \mathrm{e}^{-k t}$.

Analysis of variance was carried out on experimental data obtained from hydrolysis of ovine and caprine milk casein by all enzymes, using Excel 2000 (Microsoft Office 2000 Professional, C.P.C., Portugal). Student's $t$-test, with $P<0.05$, was employed for comparison of means.

\section{Results and discussion}

\section{Clotting activity}

The variation of the clotting time with the enzyme concentration is shown in Fig. 1. All forms of enzyme were added to reconstituted milk at final concentrations in the range $0.00025-0.00500 \mathrm{~g} / \mathrm{ml}$, thus giving rise to milk clotting times in the ranges 303-4384, 378-3615 and 230-4187 s, respectively, for cardosin A, cardosin B and a 2:1 mixture of both enzymes. The dependence of the clotting time on the enzyme concentration was estimated by fitting the model depicted in Eq. (1) to the data. The goodness of the fit is apparent in Fig. 1, and was further confirmed by the data depicted in Table 1 .

Our experimental data were also fitted to by the kinetic models proposed for milk coagulation by van Hooydonk and Walstra (1987), Kopelman and Cogan (1976) and Hyslop et al. (1979), which correlate the clotting time with the reciprocal enzyme concentration, the reciprocal clotting time with the enzyme concentration, and the

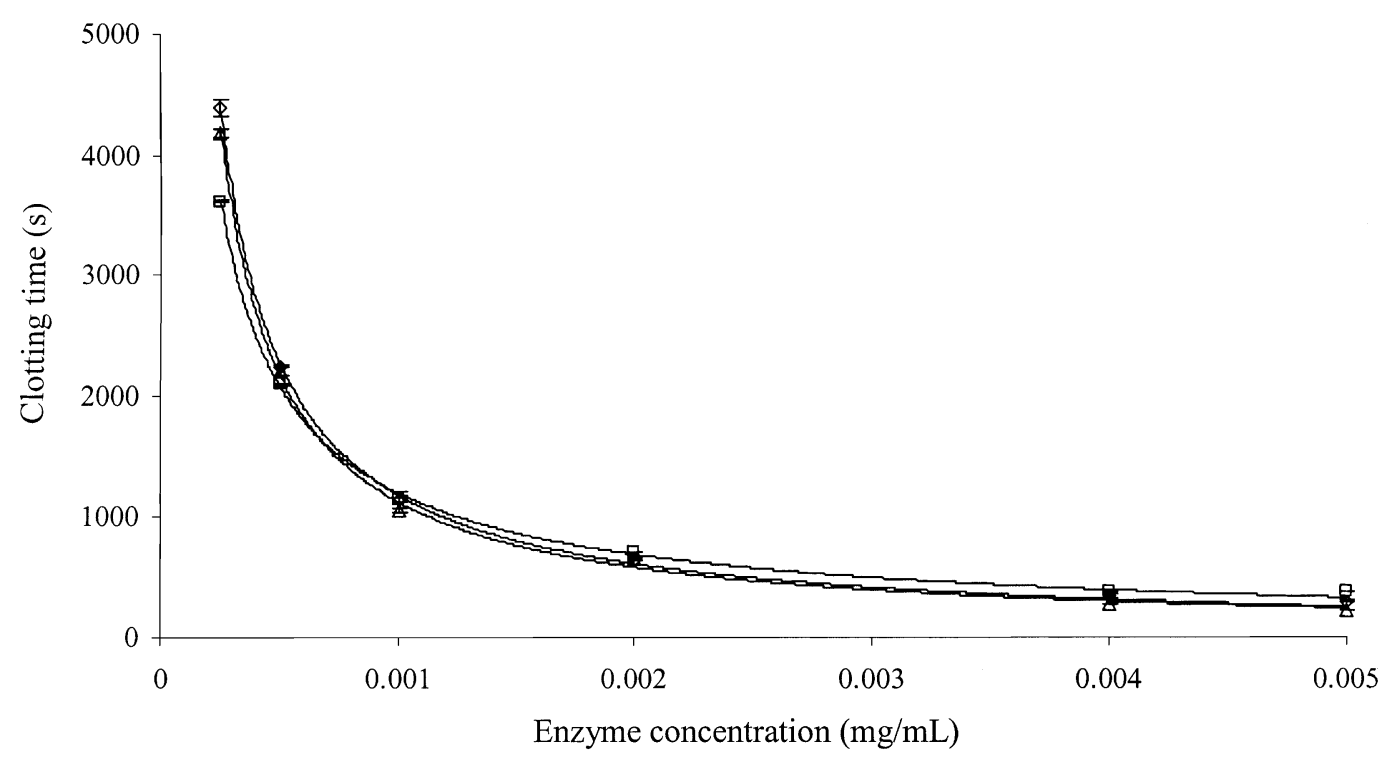

Fig. 1. Variation of clotting time with initial enzyme concentration, for cardosin $A(\diamond)$, cardosin $B(\triangle)$, and a mixture of both enzymes at the ratio 2:1 ( $\square)$; experimental data $(\diamond, \triangle, \square)$, with error bar indicating Standard Deviation and mathematical fit (Eq. (1)). 
Table 1

Best form of the model proposed by Payens et al. (1977) pertaining to clotting time $(t)$ as a function of initial enzyme concentration $\left(E_{0}\right)$, and associated correlation coefficient

\begin{tabular}{lll}
\hline Enzyme & Best model & $r^{2}$ \\
\hline Cardosin A & $t=2.527 E_{0}^{-0.8942}$ & 0.999 \\
Cardosin B & $t=5.837 E_{0}^{-0.7724}$ & 0.997 \\
Cardosin A + Cardosin B & $t=1.422 E_{0}^{-0.9652}$ & 0.996 \\
$\quad$ (ratio 2:1) & \\
\hline
\end{tabular}

clotting time with the reciprocal square root of enzyme concentration, respectively (see Table 2).

The data encompassing milk coagulation by cardosin A were well fitted to by all proposed models, although yielding a not so good correlation coefficient in the case of the model by Hyslop et al. (1979) (see Table 2). Cardosin A is believed to be similar, in terms of specificity, to chymosin (Picon, Gaya, Medina, \& Núñez, 1995); Veríssimo, Esteves, Faro, and Pires (1995) reported that the best fit for chymosin was the one relating clotting time with reciprocal enzyme concentration.

Cardosin B is believed to resemble pepsin in terms of kinetic behaviour (Veríssimo et al., 1995), and is known to possess a non-specific proteolytic activity; a slight deviation from the model proposed by van Hooydonk and Walstra was expected (Picon et al., 1995), and our results confirmed that to some degree. The other two models provided worse fits to the experimental data.

As far as the mixture of the two enzymes is concerned, Ketting and Pulay (1970) claimed that no linearly weighted relationships between clotting time and enzyme concentration are expected relative to the relationships pertaining to each enzyme in pure form; furthermore, no kinetic models pertaining to milk coagulation by mixtures of enzymes have, to our knowledge, been proposed to date. The milk coagulation by the mixture of the two aspartic proteases was fitted equally well by the models proposed by van Hooydonk and Walstra (1987) or by Kopelman and Cogan (1976); the poorer regression obtained with the model of Hyslop et al. (1979) was consistent with the not so good regressions obtained when attempting to fit the pure enzyme performance in the first place. Cardosin A is always the most abundant within the cardosin inventory in crude aqueous extracts of the flowers of $C$. cardunculus (Frazão et al., 1999), so it is expected that the catalytic behaviour of the whole mixture is somehow dominated by that exhibited by cardosin A.

\section{Proteolytic activity}

One of the most expeditious methods for assessing proteolysis in cheese is quantification of the peptides soluble in TCA, at levels between $2 \%$ and $12 \%(\mathrm{w} / \mathrm{v})$; the higher the TCA concentration, the shorter the sizes of the soluble peptides (Yvon, Chabanet, \& Pélissier, 1989).

The hydrolysis of ovine and caprine caseins brought about by cardosin A, cardosin B and a mixture of both, as shown by the production of $5 \%(\mathrm{w} / \mathrm{v})$ TCA-soluble peptides, is depicted in Fig. 2, over a period of $10 \mathrm{~h}$ of incubation under conditions prevailing during regular milk coagulation or cheese ripening conditions. The rate of hydrolysis (measured by the slope of the tangent at each point) decreases appreciably with time; the product concentration tends toward an asymptotic value by ca. 6 $\mathrm{h}$; the limiting situation is always higher when the substrate is caprine casein, and when incubation takes place under cheese ripening conditions.

The result of the fit of Eq. (8) to our experimental data, using non-linear regression analysis, yields estimates for the adjustable parameters $\varepsilon_{\mathrm{A}}, \varepsilon_{\mathrm{B}}$ and $k$, which are tabulated in Tables 3-5; the best fits are plotted in Fig. 2. The goodness of the fits is obvious from inspection of Fig. 2, and is further confirmed by the magnitude of the correlation coefficients (typically very close to unity), coupled with the significance of all parameters and the fact that the variance explained by the model is high. Note that parameters $\varepsilon_{\mathrm{A}}, \varepsilon_{\mathrm{B}}$ and $k$ should be regarded solely as adjustable parameters, so their individual physical meanings (as implied in derivation of Eq. (8)) should not be considered in a strict sense - the same

Table 2

Best form of the alternative models pertaining to clotting time $(t)$ as a function of initial enzyme concentration $\left(E_{0}\right)$, and associated correlation coefficient

\begin{tabular}{llll}
\hline Enzyme & Best model & $r^{2}$ & Reference \\
\hline Cardosin A & $t=1.074 E_{0}^{-1}+89.51$ & 0.999 & van Hooydonk and Walstra (1987) \\
& $t^{-1}=0.6534 E_{0}+0.0001556$ & 0.994 & Kopelman and Cogan (1976) \\
& $t=81.65 E_{0}^{-1 / 2}-1099$ & 0.96 & Hyslop et al. (1979) \\
Cardosin B & $t=1.161 E_{0}^{-1}-289.6$ & 0.996 & van Hooydonk and Walstra (1987) \\
& $t^{-1}=0.5191 E_{0}+0.0002701$ & 0.976 & Kopelman and Cogan (1976) \\
& $t=65.88 E_{0}^{-1 / 2}-716.9$ & 0.984 & Hyslop et al. (1979) \\
Cardosin A + Cardosin B (ratio 2:1) & $t=0.9606 E_{0}^{-1}-54.73$ & 0.999 & van Hooydonk and Walstra (1987) \\
& $t^{-1}=0.8719 E_{0}-0.000005700$ & 0.996 & Kopelman and Cogan (1976) \\
& $t=79.30 E_{0}^{-1 / 2}-1100$ & 0.973 & Hyslop et al. (1979) \\
\hline
\end{tabular}



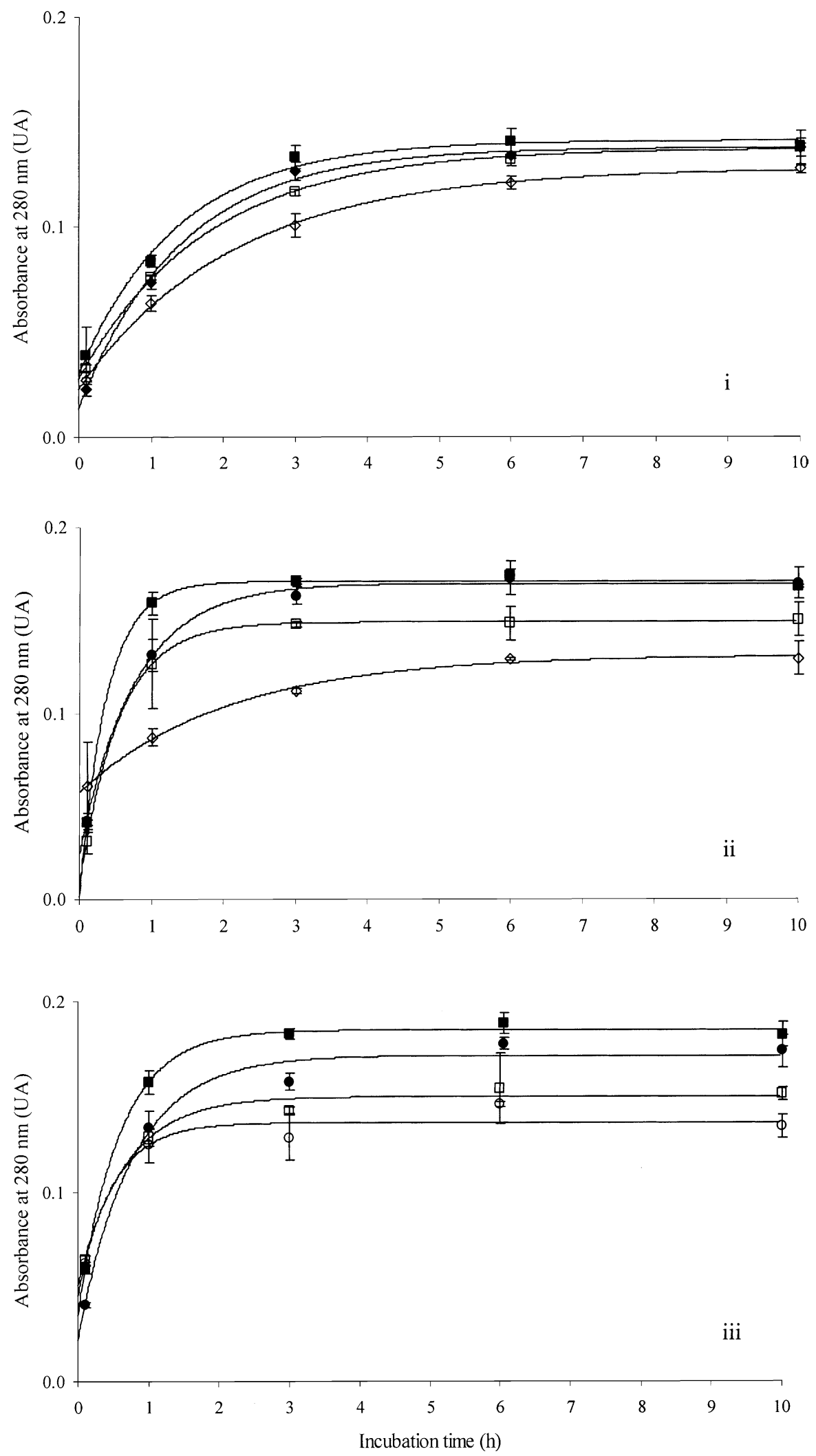

Fig. 2. Variation of absorbance (which correlates with proteolytic activity) with incubation time of ovine $(\bigcirc, \boldsymbol{\bullet})$ and caprine $(\square, \mathbf{\square})$ caseins, acted upon by cardosin A (i), cardosin B (ii), and a mixture of both enzymes at the ratio 2:1 (iii), under regular milk coagulation $(\bigcirc, \square)$ and under cheese ripening $(\bullet, \mathbf{\square})$ conditions; experimental data $(\bigcirc, \boldsymbol{\bullet}, \square, \boldsymbol{\square})$, with error bar indicating standard deviation and mathematical fit (Eq. (8)). 
Table 3

Parameter estimates of the mathematical model proposed (Eq. (5)) that describes proteolysis of ovine and caprine caseins by cardosin A, and statistical assessment of the fit

\begin{tabular}{|c|c|c|c|c|c|c|c|c|}
\hline \multirow[t]{3}{*}{ Parameters } & \multirow[t]{3}{*}{ Estimates $\pm \mathrm{SD}$} & \multicolumn{3}{|c|}{ Covariance matrix } & \multirow[t]{3}{*}{ Estimates $\pm \mathrm{SD}$} & \multicolumn{3}{|c|}{ Covariance matrix } \\
\hline & & \multicolumn{3}{|c|}{ Clotting conditions } & & \multicolumn{3}{|c|}{ Ripening conditions } \\
\hline & & $\varepsilon_{\mathrm{A}}$ & $\varepsilon_{\mathrm{B}}$ & $k$ & & $\varepsilon_{\mathrm{A}}$ & $\varepsilon_{\mathrm{B}}$ & $k$ \\
\hline \multirow[t]{2}{*}{$\begin{array}{l}\text { Ovine } \\
\varepsilon_{\mathrm{A}}\left(\mathrm{cm}^{-1} \mathrm{~mol}^{-1}\right) \\
\varepsilon_{\mathrm{B}}\left(\mathrm{cm}^{-1} \mathrm{~mol}^{-1}\right) \\
k\left(\mathrm{~s}^{-1}\right)\end{array}$} & $\begin{array}{l}1.365 \pm 0.324 \\
6.890 \pm 0.104 \\
0.7006 \pm 0.0529\end{array}$ & 0.1051 & $\begin{array}{l}0.005148 \\
0.01087\end{array}$ & $\begin{array}{r}-0.009143 \\
-0.003247 \\
0.002796\end{array}$ & $\begin{array}{l}2.981 \pm 0.635 \\
7.061 \pm 0.199 \\
0.7263 \pm 0.115\end{array}$ & 0.4027 & $\begin{array}{l}0.01569 \\
0.03959\end{array}$ & $\begin{array}{r}-0.03753 \\
-0.01282 \\
0.01315\end{array}$ \\
\hline & & \multicolumn{3}{|c|}{$R^{2}=0.994$} & & \multicolumn{2}{|c|}{$R^{2}=0.973$} & \\
\hline \multirow[t]{2}{*}{$\begin{array}{l}\text { Caprine } \\
\varepsilon_{\mathrm{A}}\left(\mathrm{cm}^{-1} \mathrm{~mol}^{-1}\right) \\
\varepsilon_{\mathrm{B}}\left(\mathrm{cm}^{-1} \mathrm{~mol}^{-1}\right) \\
k\left(\mathrm{~s}^{-1}\right)\end{array}$} & $\begin{array}{l}2.301 \pm 0.239 \\
6.394 \pm 0.108 \\
0.4627 \pm 0.0366\end{array}$ & 0.05709 & $\begin{array}{l}0.006511 \\
0.01157\end{array}$ & $\begin{array}{r}-0.004874 \\
-0.002902 \\
0.001336\end{array}$ & $\begin{array}{l}2.750 \pm 0.159 \\
6.8566 \pm 0.0603 \\
0.5643 \pm 0.0265\end{array}$ & 0.02542 & $\begin{array}{l}0.002152 \\
0.003638\end{array}$ & \multirow[t]{2}{*}{$\begin{array}{c}-0.002369 \\
-0.001085 \\
0.0007010\end{array}$} \\
\hline & & \multicolumn{3}{|c|}{$R^{2}=0.995$} & & \multicolumn{2}{|c|}{$R^{2}=0.998$} & \\
\hline
\end{tabular}

Table 4

Parameter estimates of the mathematical model proposed (Eq. (5)) that describes the proteolysis of ovine and caprine caseins by cardosin B, and statistical assessment of the fit

\begin{tabular}{|c|c|c|c|c|c|c|c|c|}
\hline \multirow[t]{3}{*}{ Parameters } & \multirow{3}{*}{ Estimates $\pm \mathrm{SD}$} & \multirow{2}{*}{\multicolumn{3}{|c|}{$\begin{array}{l}\text { Covariance matrix } \\
\text { Clotting conditions }\end{array}$}} & \multirow[t]{3}{*}{ Estimates $\pm \mathrm{SD}$} & \multicolumn{3}{|c|}{ Covariance matrix } \\
\hline & & & & & & \multicolumn{3}{|c|}{ Ripening conditions } \\
\hline & & $\varepsilon_{\mathrm{A}}$ & $\varepsilon_{\mathrm{B}}$ & $k$ & & $\varepsilon_{\mathrm{A}}$ & $\varepsilon_{\mathrm{B}}$ & $k$ \\
\hline \multicolumn{9}{|l|}{ Ovine } \\
\hline$\varepsilon_{\mathrm{A}}\left(\mathrm{cm}^{-1} \mathrm{~mol}^{-1}\right)$ & $2.437 \pm 0.636$ & 0.4049 & 0.01330 & -0.05727 & $0.1321 \pm 0.551$ & 0.3033 & 0.01171 & -0.1165 \\
\hline$\varepsilon_{\mathrm{B}}\left(\mathrm{cm}^{-1} \mathrm{~mol}^{-1}\right)$ & $8.498 \pm 0.148$ & & 0.002178 & -0.01148 & $8.555 \pm 0.0708$ & & 0.005010 & -0.008687 \\
\hline \multirow[t]{2}{*}{$k\left(\mathrm{~s}^{-1}\right)$} & $1.304 \pm 0.159$ & & & 0.02524 & $2.662 \pm 0.260$ & & & 0.06781 \\
\hline & & \multicolumn{3}{|c|}{$R^{2}=0.987$} & & \multicolumn{3}{|c|}{$R^{2}=0.997$} \\
\hline \multirow{5}{*}{$\begin{array}{l}\text { Caprine } \\
\varepsilon_{\mathrm{A}}\left(\mathrm{cm}^{-1} \mathrm{~mol}^{-1}\right) \\
\varepsilon_{\mathrm{B}}\left(\mathrm{cm}^{-1} \mathrm{~mol}^{-1}\right) \\
k\left(\mathrm{~s}^{-1}\right)\end{array}$} & & \multirow{4}{*}{0.5859} & & & & \multirow{4}{*}{1.320} & & \multirow{5}{*}{$\begin{array}{c}-0.3002 \\
-0.04333 \\
0.1778\end{array}$} \\
\hline & $5.744 \pm 0.765$ & & 0.05694 & -0.07003 & $0.7266 \pm 1.15$ & & 0.04284 & \\
\hline & $6.561 \pm 0.328$ & & 0.1075 & -0.03913 & $7.461 \pm 0.223$ & & 0.04979 & \\
\hline & $0.4845 \pm 0.167$ & & & 0.02802 & $1.830 \pm 0.422$ & & & \\
\hline & & \multicolumn{3}{|c|}{$R^{2}=0.908$} & & \multicolumn{2}{|c|}{$R^{2}=0.964$} & \\
\hline
\end{tabular}

Table 5

Parameter estimates of the mathematical model proposed (Eq. (5)) that describes proteolysis of ovine and caprine caseins by a mixture of cardosin A and cardosin B (ratio 2:1), and statistical assessment of the fit

\begin{tabular}{|c|c|c|c|c|c|c|c|c|}
\hline \multirow[t]{3}{*}{ Parameters } & \multirow[t]{3}{*}{ Estimates $\pm \mathrm{SD}$} & \multirow{2}{*}{\multicolumn{3}{|c|}{$\begin{array}{l}\text { Covariance matrix } \\
\text { Clotting conditions }\end{array}$}} & \multirow[t]{3}{*}{ Estimates $\pm \mathrm{SD}$} & \multicolumn{3}{|c|}{ Covariance matrix } \\
\hline & & & & & & \multicolumn{3}{|c|}{ Ripening conditions } \\
\hline & & $\varepsilon_{\mathrm{A}}$ & $\varepsilon_{\mathrm{B}}$ & $k$ & & $\varepsilon_{\mathrm{A}}$ & $\varepsilon_{\mathrm{B}}$ & $k$ \\
\hline \multicolumn{9}{|l|}{ Ovine } \\
\hline$\varepsilon_{\mathrm{A}}\left(\mathrm{cm}^{-1} \mathrm{~mol}^{-1}\right)$ & $2.214 \pm 0.764$ & 0.5836 & 0.02328 & -0.08832 & $3.503 \pm 0.486$ & 0.2363 & 0.007370 & -0.04520 \\
\hline$\varepsilon_{\mathrm{B}}\left(\mathrm{cm}^{-1} \mathrm{~mol}^{-1}\right)$ & $8.577 \pm 0.176$ & & 0.03087 & -0.01761 & $9.250 \pm 0.0987$ & & 0.009748 & -0.007086 \\
\hline \multirow[t]{2}{*}{$k\left(\mathrm{~s}^{-1}\right)$} & $1.312 \pm 0.195$ & & & 0.03814 & $1.704 \pm 0.155$ & & & 0.02412 \\
\hline & & \multicolumn{4}{|c|}{$R^{2}=0.983$} & \multicolumn{3}{|c|}{$R^{2}=0.994$} \\
\hline \multicolumn{9}{|l|}{ Caprine } \\
\hline$\varepsilon_{\mathrm{A}}\left(\mathrm{cm}^{-1} \mathrm{~mol}^{-1}\right)$ & $4.526 \pm 0.999$ & 0.9982 & 0.3906 & -0.4534 & $5.080 \pm 0.966$ & 0.9329 & 0.03337 & -0.2418 \\
\hline$\varepsilon_{\mathrm{B}}\left(\mathrm{cm}^{-1} \mathrm{~mol}^{-1}\right)$ & $6.826 \pm 0.177$ & & 0.03143 & -0.05678 & $7.506 \pm 0.208$ & & 0.04340 & -0.04290 \\
\hline \multirow[t]{2}{*}{$k\left(\mathrm{~s}^{-1}\right)$} & $2.032 \pm 0.667$ & & & 0.4446 & $1.504 \pm 0.420$ & & & 0.1766 \\
\hline & & \multicolumn{3}{|c|}{$R^{2}=0.944$} & & \multicolumn{3}{|c|}{$R^{2}=0.944$} \\
\hline
\end{tabular}


applies to the functional forms of models in Tables 1 and 2 regarding clotting time.

Incubation of cardosin A in citrate buffer ( $\mathrm{pH}$ 5.0), for $20 \mathrm{~h}$ at $10{ }^{\circ} \mathrm{C}$, had a significant effect on its activity upon ovine and caprine caseins $(P<0.01)$. For cardosin $\mathrm{B}$, as well as for the mixture of both enzymes, incubation at cheese ripening conditions also led to a significant increase of its activity $(P<0.01)$. These results are not surprising at all, because the cardosins are aspartic acid proteases, which possess an optimum $\mathrm{pH}$ in the acidic range and close to 5.2 (Sousa \& Malcata, 1996). Moreover, as previously indicated, cardosin B resembles pepsin in its activity and specificity (Veríssimo et al., 1995), so its activity is expected to vary favourably with incubation under ripening conditions (Andrén \& von Reedtz, 1990).

In conclusion, a simple equation that relates variation of clotting time with initial enzyme concentration appropriately describes milk coagulation by enzymes of plant origin, namely cardosins A and $\mathrm{B}$, either isolated or as a mixture. This model can be employed to predict milk clotting time by those enzymes, and eventually to optimise the coagulation process.

Previous incubation of the enzymes, under typical cheese ripening conditions, leads to a significant increase of their proteolytic activity, which is always higher upon caprine rather than ovine milk caseins. A mathematical model can appropriately describe the proteolytic activity; the overall rate of hydrolysis decreases appreciably with time, eventually reaching an asymptotic behaviour.

\section{Acknowledgements}

Financial support for author Silva was provided by a PhD fellowship (BD/18479/98), issued by programme PRAXIS XXI (FCT, Portugal). Dr. Susana C. Fonseca is hereby gratefully acknowledged for help with the statistical analysis. This research effort received partial financial support by a project grant (POCTI/AGR/ 36165/99), issued by programme POCTI (FCT).

\section{References}

Andrén, A., \& von Reedtz, C. (1990). The effects of chromatographically pure bovin chymosin and pepsin A on cheese curd firmness. Journal of Dairy Research, 57, 109-117.

Aworth, O. C., \& Muller, H. G. (1987). Cheese-making properties of vegetable rennet from Sodom apple (Calotropis procera). Food Chemistry, 26, 71-79.

Berridge, N. J. (1945). Some observations on the determination of activity of rennet. Analyst, 77, 57-72.

Domingos, A., Tavaria, F., Sousa, M. J., Malcata, F. X., Clemente, A., Brodelius, P., \& Pais, M. S. (1997). Degradation of caseins by purified extracts of Centaurea calcitrapa. Poster presented at 8 th European Congress on Biotechnology, Budapest, Hungary.
Edwards, J., \& Kosikowski, F. V. (1983). Bitter compounds from Cheddar cheese. Journal of Dairy Science, 66, 727-734.

Frazão, C., Bento, I., Costa, J., Soares, C. M., Veríssimo, P., Faro, C., Pires, E., Cooper, J., \& Carrondo, M. A. (1999). Crystal structure of cardosin A, a glycosylated and Arg-Gly-Asp-containing aspartic proteinase from the flowers of Cynara cardunculus L. Journal of Biological Chemistry, 274, 27694-27701.

Gupta, C. B., \& Eskin, N. A. (1977). Potential use of vegetable rennet in the production of cheese. Food Technology, 5, 62-66.

Hyslop, D. B., Richardson, T., \& Ryans, D. S. (1979). Kinetics of pepsin-initiated coagulation of $\kappa$-casein. Biochimica et Biophysica Acta, 556, 390-396.

Ketting, F., \& Pulay, G. (1970). In: Proceedings of the XVIII International Dairy Congress, p. 291.

Kopelman, I. J., \& Cogan, U. (1976). Determination of clotting power of milk clotting enzymes. Journal of Dairy Science, 59, 196-199.

Macedo, I. Q., Faro, C. J., \& Pires, E. V. (1993). Specificity and kinetics of the milk-clotting enzyme from cardoon (Cynara cardunculus L.) toward bovine $\kappa$-casein. Journal of Agricultural and Food Chemistry, 41, 1537-1540.

Padmanabhan, S., Chitre, A., \& Shastri, N. V. (1993). Milk clotting protease isolated from Dieffenbachia maculata. Die Nahrung, 37, 99-101.

Payens, T. A. J., Wiersma, A. K., \& Brinkhuis, J. (1977). On enzymatic clotting processes. I. Kinetics of enzyme-triggered coagulation reactions. Biophysical Chemistry, 6, 253-262.

Picon, A., Gaya, P., Medina, M., \& Núñez, M. (1995). Kinetics of milk coagulation by mixtures of cyprosin and chymosin. Milchwissenschaft, 50, 393-395.

Pires, E., Faro, C., Macedo, I., Esteves, C., Morgado, J., Veríssimo, P., Dias Pereira, C., \& Gomes, D. (1994). Flor do cardo versus quimosina no fabrico de queijos artesanais. Revista da Sociedade Portuguesa de Quimica, 54, 66-68.

Pozsar-Hajnal, K., Vamos-Vigyazo, L., Nonn-Sas, H., \& HegeduesVoelgyesi, E. (1969). Investigations of milk clotting enzymes from the point of view of cheese production. III. Selective inhibition of the proteolytic activity of plant proteases. Elelmiszertudomany, 3, 55-70.

Singh, J., Chander, H., Bhalerao, V. R., \& Dastur, N. N. (1973). Studies on vegetable rennet from Withania coagulans. Journal of Food Science and Technology - India, 10, 16-19.

Silva, S. V., \& Malcata, F. X. (1998). Proteolysis of ovine caseins by cardosin A, an aspartic acid proteinase from Cynara cardunculus L. Le Lait, 78, 513-519.

Silva, S. V., \& Malcata, F. X. (1999). On the activity and specificity of cardosin B, a plant proteinase, on ovine caseins. Food Chemistry, $67,373-378$

Silva, S. V., Allmere, T., Malcata, F. X., \& Andrén, A. (2003). Comparative studies on the gelling properties of cardosins extracted from Cynara cardunculus and chymosin on cow skim milk. International Dairy Journal, 13, 559-564.

Sousa, M. J., \& Malcata, F. X. (1996). Effects of processing conditions on the caseinolytic activity of the crude extracts of Cynara cardunculus L. Food Science and Technology International, 2, 255263

Tamer, I. M. (1993). Identification and partial purification of a novel milk clotting enzyme from Onopordum turcicum. Biotechnology Letters, 15, 427-432.

Trujillo, A. J., Carretero, C., \& Guamis, B. (1994). Los coagulantes en la industria quesera. Alimentación, Equipos y Tecnologia, 13, 91-97.

van Hooydonk, A. C. M., \& Walstra, P. (1987). Interpretation of the kinetics of the renneting reaction in milk. Netherlands Milk and Dairy Journal, 41, 19-47.

Veríssimo, P., Esteves, C., Faro, C., \& Pires, E. (1995). The vegetable rennet of Cynara cardunculus L. contains two proteinases with chymosin and pepsin-like specificities. Biotechnology Letters, 17, 621-626. 
Vieira de Sá, F., \& Barbosa, M. (1972). Cheese-making with vegetable rennet from cardo (Cynara cardunculus). Journal of Dairy Research, 39, 335-343.
Yvon, M., Chabanet, C., \& Pélissier, J.-P. (1989). Solubility of peptides in trichloroacetic acid (TCA) solutions. International Journal of Protein Research, 34, 166-176. 